\title{
Typology of Three Types of Medical Care Centers in Germany
}

V. Hulkova (Viera Hulkova)', F. Renger (Frantisek Renger) ${ }^{1,2}$, A. Czirfusz (Attila (zirfusz) $^{1}$

${ }^{1}$ St. Elizabeth University, Dept. of Public Health, Bratislava, Slovakia

${ }^{2}$ Medical Care Center, Heidenheim, Germany

\section{E-mail address:}

viera.h1@centrum.sk

\section{Reprint address:}

Frantisek Renger

Medical Care Center

Heidenheim, Germany

Suource: Clinical Social Work and Health Intervention

Pages: $50-58$

Volume: 8

Cited references: 26

Issue: 2

\section{Reviewers:}

Victor Namulanda Wanjala

Catholic university of Eastern Africa, Nairobi, Kenya

Gabriela Lezcano

University of California, San Francisco, USA

\section{Key words:}

Health Care Management (HCM), Usual MCC Partnership, Usual MCC Company, MCC Corporation, MCC Classification, MCC Typology, MCC Synergy Effects.

\section{Key message:}

In 2004, the German Legislature approved medical centers for statutory-health-insurance-accredited medical care. This resulted in fundamental changes to the German Healthcare System.

\section{Publisher:}

International Society of Applied Preventive Medicine i-gap

CSWHI 2017; 8(2): 50 - 58; DOI 10.22359/cswhi_8_2_10 @ 2017 Clinical Social Work and Health Intervention

\section{Abstract:}

In 2004, the German Legislature approved medical centers - or MCCs for short (German: MVZs) - for statutory-health-insurance-accredited 
(short: SHI) medical care. This resulted in fundamental changes to the German Healthcare System the effects of which are far from being clarified. The Legislature expects the structural changes to result in improved interconnections between the In-patient and Out-patient Sectors.

\section{Object of enquiry:}

Growth will also be recorded by those types of MCC which are managed by other SHI service providers, because the synergy effects from these forms of cooperation can be clearly seen.

Aims:

The aim of the study is to show that there exist three different types of MCCs in Germany and what the concrete characteristics of these types are.

\section{Methodology:}

A semi-standardized questionnaire was assessed on the MCCs to receive the relevant data.

\section{Results:}

There are three types of MCCs in Germany:

the usual MCC/partnership,

the usual MCC/corporation,

the company MCC.

Through the developments in the medical field it has become noticeable in the last few years that the MCC in Germany has definitely attained a particular position of importance.

\section{Conclusion:}

The following paper on the classification of MCCs in Germany shows the results of the study carried out in December 2011, the results of which are presented in an empirical classification of MCCs. The structure of the German MCC is an excellent type for the medical field and has very good prospects for the future.

\section{Introduction}

On 01/01/2014, the German Legislature approved Medical Care Centers (in short: MCCs) for statutory health insurance medical care. As a result, changes regarding the healthcare system in Germany have taken place the effects of which are far from being clarified. A clear type identification of this new healthcare/economic field has not been available up until this point, even if the topic of MCCs has been dealt with by various authors, for example Frielingsdorf (3), Distler (1), Blümm (2) and Sörensen (15), to name but a few.

In his Dissertation, Medizinische Versorgungszentren in Deutschland: Entwicklung einer Typologie unter Unternehmensführungsaspekten [MCCs in Germany: The 
development of a typology under company management perspectives], Renger shows approaches for a clear typology of MCCs. This study shows the first results Hulkova, Renger and Czirfusz were able to achieve within the scope of forming a typology according to Kluge's method.

\section{Material and Methods}

Objects of investigation are to include all MCCs in Germany in order to come to a compre-hensively and empirically validated typology to the furthest extent possible. As a scientific method, a semi-standardized questionnaire was used. It was distributed to the MCCs in Germany via e-mail and supported by conducting telephone surveys. It is evident that despite a response rate of $5.33 \%$ (usual for this type of survey), an initial typology was definitely able to be formed using the examination material.

\section{Three MCC Types/Empirical MCC Type classification/Devising Relevant Comparative Dimensions}

In order to typify MCCs based on various aspects, first a differentiation can be established according to member types:

- Freelance Doctor/Panel Doctor

- Hospital

- Affiliated Group/Management Company (4-5).

Furthermore, a differentiation can be made with regard to what status the Doctors have that work at the MCC:

- the MCC works exclusively with Panel Doctors,

- the MCC works with Panel Doctors and Employed Doctors,

- the MCC works exclusively with Employed Doctors.
Since three characteristic features are involved here, initially a "feature space" is established consisting of nine combination options (5).

Since it has been shown within the scope of literature that there are preferences in terms of this (for example, that Management Companies that operate MCCs almost always only work with Employed Doctors, something which also frequently concerns hospitals that operate an MCC (1)), the feature space is classified in the form of a typological reduction (5-7) in such a way that the empirical types adequately correspond to the majority of MCCs existing in Germany (see Figure 1 on the following page).

By forming the feature space, seven Basic Types of MCCs form in Germany:

- Basic Type, Freelancer MCC

- Basic Type, Hospital MCC

- Basic Type, Affiliated Group MCC

- Basic Type, Freelancer MCC with EmployedDoctors

- Basic Type, Hospital MCC with Panel Doctors

- Basic Type, Affiliated Group MCC with the involvement of Freelance Doctors

- Basic Type, Affiliated Group MCC involving a Hospital

The two Basic Types/the one Basic Type that is still conceivable - Freelancer/Hospital $\mathrm{MCC}$ - is not sensible since this would mean that the majority of the partnership shares are not taken into consideration. Although this is basically also the case for types 6 and 7 it seems difficult to imagine that a Freelancer MCC would involve a Hospital in the minority and then only work with Employed Doctors or, in other words, that a Hospital would involve a Freelancer in the minority and then only work with Panel Doctors. 
Figure 1: Feature space of empirical MCC Types

\begin{tabular}{|l|l|l|l|}
\hline MCC types & \multicolumn{3}{|c|}{ Doctor status } \\
\hline $\begin{array}{l}\text { Member } \\
\text { Type }\end{array}$ & Panel_Doctor & $\begin{array}{l}\text { Panel Doctor / } \\
\text { Employed Doctor }\end{array}$ & $\begin{array}{l}\text { Employed } \\
\text { Doctor }\end{array}$ \\
\hline Freelancers & $\begin{array}{l}\text { Basic Type, } \\
\text { Freelancer MCC }\end{array}$ & Basic Type, Freelancer MCC with Employed Doctors \\
\hline Hospital & $\begin{array}{l}\text { Basic Type, Hospital MCC with Panel } \\
\text { Doctors }\end{array}$ & $\begin{array}{l}\text { Basic Type, Hospital } \\
\text { MCC }\end{array}$ \\
\hline $\begin{array}{l}\text { Affiliated } \\
\text { Group }\end{array}$ & $\begin{array}{l}\text { Basic Type, } \\
\text { Affiliated Group } \\
\text { MCC with the } \\
\text { involvement of } \\
\text { Freelance Doctors }\end{array}$ & $\begin{array}{l}\text { Basic Type, affiliated } \\
\text { Group MCC involving } \\
\text { a hospital }\end{array}$ & $\begin{array}{l}\text { Basic Type, Affiliated } \\
\text { Group MCC }\end{array}$ \\
\hline
\end{tabular}

\section{Grouping of Cases and Analysis of Empirical Regularities}

In the following, the MCCs in Germany are grouped based on the KBV 2008 MCC Survey (8) and classified using the legal-form criteria (see Figure 2). The results are revealed from the Internet survey that was conducted during from December 2011 to January 2012. The typology-forming method type is orientated on the method presented by Kluge. (4-5)

The Basic Type Freelancer MCC with Employed Doctors is the most prevalent, exclusively in the legal form $\mathrm{GmbH}$ (37.5\%). The Basic Type Freelancer MCC follows with a company distribution of the legal form GbR being 25\% and partnership companies being $12.5 \%$.

Figure 2: Distribution of the basic MCC types in Germany with regard to their legal form

\begin{tabular}{|c|c|c|c|c|c|c|}
\hline Legal form of MCC types & \multicolumn{6}{|c|}{ Legal form } \\
\hline MCC Basic Type & GbR & PartG & $\mathrm{GmbH}$ & $\mathrm{AG}$ & $\mathrm{KG}$ & $\mathrm{GmbH} \& \mathrm{CoKG}$ \\
\hline 1 Freelancers & $\begin{array}{c}2 \\
25 \%\end{array}$ & $\begin{array}{c}1 \\
12.5 \%\end{array}$ & - & - & - & - \\
\hline 2 Hospital & - & - & $\begin{array}{c}1 \\
12.5 \%\end{array}$ & - & - & - \\
\hline 3 Affiliated Group & - & - & $\begin{array}{c}1 \\
12.5 \%\end{array}$ & - & - & - \\
\hline $\begin{array}{l}4 \text { Freelancers }+ \\
\text { Employed Doctors }\end{array}$ & - & - & $\begin{array}{c}3 \\
37.5 \%\end{array}$ & - & - & - \\
\hline $\begin{array}{l}5 \text { Hospital }+ \\
\text { Panel Doctors }\end{array}$ & - & - & - & - & - & - \\
\hline $\begin{array}{l}\text { 6. Group }+ \text { Involvement of } \\
\text { Freelance Doctors }\end{array}$ & - & - & - & - & - & - \\
\hline $\begin{array}{c}\text { 7. Group + Involvement of } \\
\text { a Hospital }\end{array}$ & - & - & - & - & - & - \\
\hline
\end{tabular}


The Basic Type Hospital MCC has the legal form $\mathrm{GmbH}$ (12.5\%); as does the Basic Type Affiliated Group MCC (12.5\%). (11-13) Figure 3 shows these aspects:

\section{Context analysis}

- Basic Type affiliated Group MCC as large $\mathrm{MCC}$ or MCC Company $(12.5 \%)$,

- Basic Type Freelancer MCC with Employed Doctors as a medium-size MCC (12.5\%),

Figure 3: Relationship between basic MCC type and number of staff

\begin{tabular}{|c|c|c|c|}
\hline $\begin{array}{c}\text { Number of staff } \\
\text { of MCC types }\end{array}$ & \multicolumn{3}{|c|}{ Number of staff } \\
\hline MCC Basic Type & $\begin{array}{c}\text { Small MCC/Legal } \\
\text { Alternative to Joint } \\
\text { Practice 1-5 Staff } \\
\text { Members }\end{array}$ & $\begin{array}{c}\text { Medium-sized } \\
\text { MCC/Standard } \\
\text { Size MVZ 6-40 } \\
\text { Staff Members }\end{array}$ & $\begin{array}{c}\text { Large MCC/MCC } \\
\text { Company } \\
\text { More than 40 } \\
\text { Members of Staff }\end{array}$ \\
\hline 1 Freelancers & - & 3 & 1 \\
\hline 2 Hospital & - & $37.5 \%$ & $12.5 \%$ \\
\hline 3 Affiliated \\
Group
\end{tabular}$\quad-\quad$\begin{tabular}{c}
1 \\
\hline $\begin{array}{c}\text { 4 Freelancers }+ \\
\text { Employed Doctors }\end{array}$
\end{tabular}

The Basic Type Freelancer MCC (37.5\%) in the form of a medium-size MCC is the most prevalent. With the same distribution, one sees the variations:

- Basic Type Freelancer MCC as the largest MCC and MCC Company $(12.5 \%)$,

- Basic Type Hospital MCC as a medium-size MCC (12.5\%),
- Basic Type Freelancer MCC with Employed Doctors as a large MCC or MCC Company (12.5\%).

\section{Classification}

In Figure 4 the relationship is shown between the respective basic MCC Type and the related number of staff. 
Figure 4: Formation of MCC Types

\begin{tabular}{|c|c|c|c|}
\hline MCC Basic Types & \multicolumn{3}{|c|}{ Number of staff } \\
\hline Legal form & $1-5$ & $6-40$ & $>40$ \\
\hline $\mathrm{GbR}$ & \multirow{6}{*}{$\begin{array}{c}\text { Cannot be } \\
\text { evaluated } \\
\text { by means of } \\
\text { a survey }\end{array}$} & $\begin{array}{c}2(25 \%) \\
\text { Type } 1 \\
\text { "usual MCC/Partnership" }\end{array}$ & $\begin{array}{c}\text { Cannot be } \\
\text { evaluated by } \\
\text { means of a survey }\end{array}$ \\
\hline PartG & & $\begin{array}{c}\text { Cannot be evaluated by } \\
\text { means of a survey }\end{array}$ & $\begin{array}{c}1(12.5 \%) \\
\text { Type } 3 \\
\text { "company MCC" }\end{array}$ \\
\hline $\mathrm{GmbH}$ & & $\begin{array}{c}3(37.5 \%) \\
\text { Type } 2 \\
\text { "usual MCC/Corporation" }\end{array}$ & $\begin{array}{c}2(25 \%) \\
\text { Type } 3 \\
\text { "company MCC" }\end{array}$ \\
\hline $\mathrm{AG}$ & & \multirow{3}{*}{\multicolumn{2}{|c|}{ Cannot be evaluated by means of a survey }} \\
\hline $\mathrm{KG}$ & & & \\
\hline $\mathrm{GmbH} \& \mathrm{CoKG}$ & & & \\
\hline
\end{tabular}

Three different MCC types are formed, the "usual MCC/partnership company" (25\%), the "usual MCC/Corporation" (37.5\%) and the "company MCC" (37.5\%). The constellations that were not able to be ascertained by means of the survey are marked as "cannot be evaluated".
In Figure 5, the three MCC types developed are shown in a graphical representation.

Only two different Basic Types result from the criteria legal form and number of staff: the ,usual $\mathrm{MCC}^{\prime \prime}$ and the „company MCC" (6-7; 11-13).

Figure 5: Graphical representation of the depicted MCC types

\begin{tabular}{|c|c|c|c|}
\hline MCC Basic Types & \multicolumn{3}{|c|}{ Number of staff } \\
\hline Legal form & $1-5$ & $6-40$ & $>40$ \\
\hline $\mathrm{GbR}$ & \multirow{6}{*}{$\begin{array}{l}\text { Cannot be } \\
\text { evaluated } \\
\text { by means of } \\
\text { a survey }\end{array}$} & $\begin{array}{l}\text { Type } 1 \text { "usual MCC/ } \\
\text { partnership" }\end{array}$ & \multirow{3}{*}{$\begin{array}{c}\text { Type } 3 \\
\text { “company MCC" }\end{array}$} \\
\hline PartG & & & \\
\hline $\mathrm{GmbH}$ & & $\begin{array}{c}\text { Type } 2 \\
\text { "usual MCC/corporation" }\end{array}$ & \\
\hline $\mathrm{AG}$ & & & \\
\hline $\mathrm{KG}$ & & & \\
\hline GmbH\&CoKG & & & \\
\hline
\end{tabular}




\section{Results and Discussion}

\section{Characterization of the types depicted}

The three types presented, ,usual MCC/ Partnership“, „usual MCC/Corporation“ and „Company MCC“, most clearly differ from each other with regard to their respective size, the number of staff and the choice of legal form. While the usual MCC in both legal forms can be seen as a medium-size MCC, in the case of the company MCC, the size of the unit involved becomes clear. This is expressed by the number of staff and due to the fact that the choice of selecting GbR as a legal form for such a large unit can be viewed as being unlikely. Following these interpretations, in practice, it can be certainly assumed that within the scope of structural healthcare-system considerations in Germany and particularly concerning MCCs, it is clear that MCCs are middle-size and large units (4-5).

The typological structure of MCCs could only be explained at the beginning of the investigation by converging them. Observing the German Healthcare System and establishing a connection to the development of MCCs brought about new insight that was then deepened by defining the research gap. Due to both empirical studies that were conducted, it was possible to focus on the precisely formed typological structure of the MCCs. The three forms presented sub-MCC/P, sub-MCC/H and CMCC (for abbreviations, see above) - were dealt with with very precise orientation on economic functions with regard to company management. It was evident that there are significant differences with regard to the types in terms of their orientation on the economic functions that are set up. One part of the paper forms the definition of the object to be studied and also the presentation of the research gap. It was a difficult process to filter out the basic MCC types with regard to the Healthcare System (9-13).

\section{Conclusions}

According to Sörensen (15), patients have a need for information concerning health policy questions and their own medical care. However, it was determined within the scope of this empirical study that the knowledge of those questioned covered by statutory insurance is only at a low level concerning the system, services and costs. According to Blümm (2), only those MCCs managed at a medical level that operate under the special form of branch MCCs or as an MCC chain will show further evident growth in contrast to individual MCCs managed at a medical level.

According to Sassen and Franz (14), a Doctor is no longer exclusively bound to his Panel Doctor location and has the possibility of also carrying out his/her Panel Doctor activities at other locations (branch practice) according to Section 24 (3) of the Doctor Authorization Regulation (ZV-Ärzte). However, this fact only applies under the following conditions:

\section{The care of the insured is improved at the other locations}

The proper care of the insured at the location of the Panel Doctor's office is not impaired.SHI-accredited Doctor's Associations currently hold the view that this criterion is orientated on requirement planning, which means that only if a Panel Doctor location is free or will become free will there be options to improve medical care (14-18). There are three different Basic Types of MCCs in Germany: The usual MCC/Partnership Company, the usual MCC/Corporation and the Affiliated Group MCC or Company MCC. Further investigations on this topic must show what exact characteristics these three types have. 


\section{References}

1. DISTLER B (2012). Die Einführung Medizinischer Versorgungszentren und ihre Auswirkungen auf den Arzt als Freiberufler. In: Schriftenreihe Gesundheitsmanagement und Medizinökonomie. Hamburg: Verlag Dr. Kovac, 389 p. ISBN: 9783540304357.

2. BLUMM B (2009). Chancen des Medizinischen Versorgungszentrums im Deutschen Gesundheitswesen, Diss. St.Elisabeth-Universität Bratislava. In: Munchen, GRIN Verlag, 119 pp; ISBN: 978-3-8428-0361-9 / online publication: URL: http://www.diplom. de/Chancen-Medizinischen-Versorgungszentrums-Deutschen-Gesundheitswesen/ 15361.html, (accessed: 04. 01. 2012).

3. FRIELINGSDORF O (ed.) (2009). Professionelle Leitung eines $M V Z$-Komprimiertes Hintergrundwissen zu Management-Aufgaben im MVZ Ecomed MEDIZIN, Verlagsgruppe Hüthig Jehle Rehm, 360 p. ISBN: 978-3-609-51563-2.

4. KLUGE S (1999). Empirisch begründete Typenbildung - Zur Konstruktion von Typen und Typologien in der qualitativen Sozialforschung. Opladen (Germany): VS, 227(1):296-1, ISBN: 978-3810022646.

5. KLUGE S (2000). Empirisch begründete Typenbildung in der qualitativen Sozialforschung. FQS. 2000, 1(1): 11-1. Epub; Art. 14; URL: http://nbn-resolving.de/urn:nbn: de:0114-fqs0001145, (accessed: 10 August 2011).

6. LAZARSFELD PF (1937). Some Remarks on the Typological Procedures in Social Research. Zeitschrift für Sozialforschung. Vol. 6 134(2):139-119.

7. LAZARSFELD PF BARTON AH (1951). Qualitative Measurement in the Social Sciences - Classification / Typologies / Indices. In: LERNER, D., LASSWELL, H., D., (Eds.).: The Policy Sciences. Stanford University Press, p. 192-155.

8. MVZ-SURVEY (2008). (KBV), URL: http //:www.kbv.de/koop/9173.html, (accessed: 07/12/2014).
9. RENGER F (2012a). Typisierung des Medizinischen Versorgungszentrums von Freiberuflern als Beitrag zur Unternehmensführun.. Munchen: GRIN Verlag., 9 p. ISBN: 978-3-656-12258-6.

10. KIMULI D, MIKLOSKOVA M, SPANIK S, SUVADA J, ADAMCOVA J, TOMANEK P, KAFKOVA J, CZARNECKI P (2016). Social Pathology II. Warszaw, Management University, 2016. pp.: 455.

11. KAFKOVA J, SILHAROVA B, KRCMERY V, ABDO HASAN A (2017). Late presenters among HIV-positive patients, attending a rural comprehensive care clinic in Southern Uganda. ECCMID 2017.

12. SZABO I, KULKOVA N, SOKOLOVA J, MIKOLASOVA G, SUVADA J, KALAVSKA A, DOBRODENKOVA S, MATEICKA F, KAFKOVA J, NKONWA I (2013). Neurologic complications and sequellae of infectious diseases in Uganda and Kenya: Analysis of 288 cases from two rural hospitals. In Neuroendocrinology Letters Vol. 34, Suppl 1, 2013, Pages 28-31.

13. GREY E, HARDY M, SLADECKOVA V, ADAMCOVA J, BUCKO L, BLASKOVIC J, PAUEROVA K, DUDASOVA T, POLONOVA J, RABAROVA L, BENCA J (2013). Neurologic disorders in HIV-positive orphans: 10 years of follow up. Neuroendocrinology Letters Vol. 34, Suppl 1, 2013, Pages 36-40.

14. BENCA J, ONDRUSOVA A, ADAMCOVA J, TAKACOVA M, POLONOVA J, TAZIAROVA M (2007). Ten years experience with 497 cases of neuroinfections in tropic: in limited laboratory infrastructure initially treat both, cerebral malaria and meningitis. Neuroendocrinology Letters Vol. 28, Suppl 2, June 2007, Pages49-50.

15. MULI J M, SECKOVA S, SLADECKOVA V, ADAMCOVA J, RABAROVA L, TAKACOVA M, POLONOVA J, DUDASOVA T, PAUEROVA K, NAMULANDA V, OKOTH V, JUMA O, DIANA E, JOHNSON J, DEADLINE J, BARTKOVJAK M, 
KOLENOVA A, TAZIAROVA M, BENCA J, NJAMBI Z (2007). Meningococcal meningitis is still the commonest neuroinfection in the community in tropics: overview of 62 cases. Neuroendocrinology letters Vol 28, Suppl 3, Nov 2007, Pages 23-24.

16. MULI J M, SECKOVA S, SLADECKOVA $\mathrm{V}$, STENO J, ADAMCOVA J, RABAROVA L, TAKACOVA M, POLONOVA J, DUDASOVA T, PAUEROVA K, NAMULANDA V, OKOTH V, JUMA O, DIANA E, JOHNSON J, DEADLINE J, BARTKOVJAK M, KOLENOVA A, TAZIAROVA M, BENCA J, NJAMBI Z (2007). Meningitis in diabetic patients. Neuroendocrinology letters Vol 28, Suppl 3, Nov 2007, Pages 28-29.

17. POLONOVA J (2015). Respiratory infections after camping in free nature are the current diseases in Migrants to Austria and Germany via Hungary in September 2015: Experience from Röszke and Vámoszabadi. In Krcmery V, Liskova A, Mrazova M, Herdics G, Khali I, Polonova J, Suvada J, Bucko L, Bibza M, Ondova P, Hajj P, Fer I. Clinical Social Work, 2015; 5(2 2015) 33-35. ISSN:2222-386X.

18. POLONOVA J (2015). Self-acceptance, self-esteem building and experiencing of healthy sexuality among youth as the prevention of an abuse in partnerships In Suvada, J. - Tománek, P. (eds.), 2015. Social pathology among youth (abstract book). Bratislava: St. Elisabeth University of Health and Social Work Bratislava, 2015. ISBN 978-80-8132-131-3. 73 - 74 p.

19. BELOVICOVA M, ADAMCOVA J, KAFKOVAJETAL(2017). Lowincidence of MRSA among úphysiotherapy patients. Clin Soc Work Health Intervention, vol.8.2017,1,3335. ISSN 2076-9741/Online.
20. RENGER F (2012b). Unternehmensführungsgesichtspunkte des Medizinischen Versorgungszentrums, insbesondere der Beschaffung, Finanzierung/Investition und des Qualitätsmanagements. Munchen: GRIN Verlag, 10 p. ISBN: 978-3-656-13461-9.

21. RENGER F, CZIRFUSZ (2013A). Empirical Study on the Classification of Medical Centers. International Journal for Applied Management Science \& Global Developments. Vol. 2, p. C4(1)-C4(7). ISSN: 2195-4135.

22. BAK T, MIERZWA J, JURJEWICZ H (2015). Religion and Spirituality in Social Work Practice. New Jersey 2015. 101 s. ISBN 978-0-9967396-2-7.

23. RENGER F (2014.) Typologische Strukturen der Unternehmensführung im Medizinischen Versorgungszentrum, $\mathrm{PhD}$ thesis. Bratislava: St. Elisabeth-Universität Bratislava, $84 \mathrm{p}$.

24. RENGER F (2015). Medizinische Versorgungszentren in Deutschland: Entwicklung einer Typologie unter Unternehmensführungsaspekten. Doctoral thesis, Bratislava: St. Elisabeth-Universität Bratislava, 96 p.

25. SASSEN S, FRANZ M (eds.) (2007). Zuweisermarketing und sektorenübergreifende Kommunikation - Ein Kompendium zur gezielten Einflussnahme auf Patientenströme und transsektorale Versorgungsqualität, Economica, Heidelberg: Verlagsgruppe Hüthig Jehle Rehm, p. 6-384. ISBN: 978-3870815363.

26. SORENSEN C (2011). Kostenerstattung im ambulanten Gesundheitswesen - Ein informationsökonomische Betrachtung der Effekte und empirische Analyse. Hamburg: Verlag, Dr. Kovac 325 p. ISBN: 978-3830060659. 